\title{
Effects of early intervention strategies using telehealth on an infant with Down
}

\section{syndrome: A case study}

Efeitos das estratégias de intervenção precoce usando telessaúde em uma criança com síndrome de

Down: Um estudo de caso

Efectos de las estrategias de intervención temprana con telesalud en un bebé con síndrome de

Down: Un estudio de caso

Received: 04/10/2021 | Reviewed: 04/16/2021 | Accept: 04/19/2021 | Published: 04/28/2021

Eloisa Tudella

ORCID: https://orcid.org/0000-0003-0824-7350 Federal University of São Carlos, Brasil E-mail:elotudella@gmail.com

Carolina Fioroni Ribeiro da Silva

ORCID: https://orcid.org/0000-0002-7724-6020 Federal University of São Carlos, Brasil E-mail: carolinafrdasilva@gmail.com

Clarissa Cotrim dos Anjos Vasconcelos

ORCID: https://orcid.org/0000-0002-7983-7350

State University of Sciences of Alagoas, Brazil E-mail: clacotrimanjos@gmail.com

\begin{abstract}
Purpose: To present the strategies used and the effects of early physiotherapy intervention using telehealth on a Down syndrome infant. Materials and methods: An infant diagnosed with Down syndrome performed the early intervention. Telehealth was performed synchronously according to the biopsychosocial model The assessments were carried out using the International Classification of Functioning, Disability and Health checklist. The Alberta Infant Motor Scale and the Brazilian version of the Affordances in the Home Environment for Motor Development - Infant scale were used to assess the activity component and environmental factors, respectively. Evaluations were performed at 5, 50, 79, and 105 days of corrected age. Results: The infant obtained progressive and constant gains during 100 days of early intervention. It is known that environmental and personal factors interfere with the performance of the infant's skills. Conclusion: Early intervention initiated in the first month of life using telehealth in an infant with Down syndrome proved an effective intervention method.
\end{abstract}

Keywords: Early intervention; Telemonitoring; Telereahabilitation; Down syndrome.

\begin{abstract}
Resumo
Objetivo: Apresentar as estratégias utilizadas e os efeitos da intervenção fisioterapêutica precoce por meio da telessaúde em uma criança com síndrome de Down. Materiais e métodos: Uma criança com diagnóstico de síndrome de Down realizou a intervenção precoce. A telessaúde foi realizada de forma síncrona segundo o modelo biopsicossocial. As avaliações foram realizadas por meio da Classificação Internacional de Funcionalidade, Incapacidade e Lista de verificação de saúde. A Alberta Infant Motor Scale e a versão brasileira da escala Affordances in the Home Environment for Motor Development - Infant foram utilizadas para avaliar o componente de atividade e os fatores ambientais, respectivamente. As avaliações foram realizadas aos 5, 50, 79 e 105 dias de idade corrigida. Resultados: O lactente obteve ganhos progressivos e constantes ao longo de 100 dias de intervenção precoce. Sabe-se que fatores ambientais e pessoais interferem no desempenho das habilidades do bebê. Conclusão: A intervenção precoce iniciada no primeiro mês de vida por meio da telessaúde em uma criança com síndrome de Down mostrou-se um método de intervenção eficaz.
\end{abstract}

Palavras-chave: Intervenção precoce; Telemonitoramento; Telereabilitação; Síndrome de Down.

\section{Resumen}

Objetivo: Comparar la calidad de vida, la percepción de salud e ingresos entre familias con y sin riesgo socioeconómico durante la pandemia de COVID-19. Métodos: En este estudio transversal participaron 41 madres de recién nacidos sanos a término ( $\geq 37$ semanas), que se subdividieron en dos grupos: 1) riesgo socioeconómico (G-R); y 2) sin riesgo socioeconómico (G-SR). La calidad de vida se midió mediante el instrumento Quality of Life-Bref de la Organización Mundial de la Salud (WHOQOL-Bref). La percepción de salud y los ingresos mensuales se midieron mediante un cuestionario elaborado por los autores. Resultados: Se encontró una diferencia significativa entre los grupos G-R y G-SR para el dominio ambiental $(\mathrm{p}=0.001)$ de la WHOQOL-Bref. La percepción de salud durante la pandemia de COVID-19 de las madres en el G-R fue entre buena $(52,6 \%)$ y regular $(36,8 \%)$ mientras que la mayoría 
de las madres en el G-SR calificaron su salud como buena (81,8\%). De las familias sin riesgo socioeconómico, el 59\% solicitó ayuda del gobierno, mientras que la mayoría de las familias de bajo nivel socioeconómico (89,5\%) fue beneficiada por el auxilio de emergencia del gobierno. Conclusiones: Las familias de bajo nivel socioeconómico presentaron peor calidad de vida en el ámbito ambiental, peor percepción de salud y disminución de los ingresos familiares en comparación con las familias sin riesgo socioeconómico.

Palabras clave: Intervención rápida; Telemonitorización; Telerreahabilitación; Sindrome de Down.

\section{Introduction}

Down syndrome is a genetic condition caused by an error in cell division, leading to an extra copy of chromosome 21 (Schwartzman, 2003). Its incidence is higher in mothers with advanced maternal age. Approximately 3 in every 5,000 infants are born with Down syndrome worldwide (World Health Organization, 2020; Federação Brasileira das Associações de Síndrome de Down. Síndrome de Down, 2020), and it affects 1 per every 700 live births in Brazil (270 thousand people) (Brazil, 2019).

The most common defects in body structures and functions are cardiac malformations, gastrointestinal and thyroid disorders, hematological diseases, visual changes, hearing loss, orthodontic problems, orthopedic changes, reduced brain volume, hypotonia, ligament laxity, joint hypermobility, and sensory and intellectual deficits (Brazil, 2013; Contestabile, Benfenati, Gasparini.,2010; Pinero-Pinto et al., 2020). These defects may persist throughout life and contribute to the delayed motor, cognitive, language, learning, and behavioral developments (Pereira et al.,2013; Ferreira-Vasques, Lamonica, 2015; Tudella et al. 2011; Lauteslager, 2020).

Several other factors related to the political, social, and global contexts (Tomopoulos et al., 2006) (i.e., social isolation and the negative aspects caused by the COVID-19 pandemic) together with genetic factors may potentiate the neuropsychomotor development delay (Araujo et al. 2020). In addition, the pandemic context affects income, health, and quality of life, not only for people of low socioeconomic status but also for medium and high socioeconomic levels (Greco, Silva, Moraes, Menegussi, Tudella, 2021).

Therefore, the identification and early referral of these infants (up to three months of age) to specialized early intervention programs are of utmost importance (Tudella et al., 2000; Herskind, Greisen, Nielsen, 2015; Tudella, Toledo, Lima-Alvarez, 2019; Tudella, 1989). Early intervention is characterized as a secondary prevention activity that prevents or attenuates alterations in body structures and functions to minimize activity limitations, the effects of dysfunctions on delayed gross and fine motor developments, and social participation restrictions, distancing motor age from chronological age (Tudella et al.,2000; Tudella, Toledo, Lima-Alvarez, 2019; Brandão, 1992). It is based on the greatest maturation and plasticity period of the central nervous system since the infant is more susceptible to sensory inputs and more responsive to some stimuli, allowing motor learning and cognitive development (Tudella et al., 2000; Hadders-Algra, 2011; Ismail, Fatemi, Johnston, 2017). During this period, the infant is more susceptible to sensory inputs and more responsive to some stimuli, allowing motor learning and cognitive development (Ismail, Fatemi, Johnston, 2017). It is known that the stimuli must be pleasurable to motivate the infant to seek that specific stimulus one more time through self-generated movements, favoring motor learning and functional and effective movements (Tudella, Toledo, Lima-Alvarez, 2019). Corroborating with this idea by Novak et al. (Novak et al., 2017) stated that early intervention maximizes neuroplasticity and minimizes deleterious changes in bone loss, growth, and development.

In March 2020, the Brazilian government decreed social isolation to control and prevent COVID-19. Due to its high transmission power, it is known that the most effective way to control the spread of COVID-19 is social isolation (World Health Organization,2019). The society needed to adapt to the public health authority demands and the new forms of relationships. Thus, the Federal Council of Physiotherapy and Occupational Therapy (COFFITO) (Article 2 of Normative Resolution 516 of March 20, 2020) allowed the non-face-to-face assistance using telehealth (Federal Council of Physiotherapy 
and Occupational Therapy., 2020). Telehealth is defined as any specialized professional strategy conducted remotely using information and communication technologies to improve access between patients and professionals (Minghelli et al.2020).

This new form of physiotherapy allowed both the continuity and the beginning of early intervention in at-risk infants. Therefore, early intervention using telehealth was initiated in a Down syndrome infant, one of the first Brazilian telehealth attendances. Due to the importance of telehealth during the pandemic, it is essential to present the effects of early intervention strategies using telehealth on the motor development of a Down syndrome infant, initiated at 35 days of age. The results of this study may benefit physiotherapists and researchers in understanding early intervention strategies using telehealth for Down syndrome infants.

This study aims to present the strategies used and the effects of early physiotherapy intervention using telehealth on a Down syndrome infant. Early intervention was performed using the International Classification of Functioning, Disability and Health (World Health Organization,2001) according to the biopsychosocial model (Farias, Buchalla, 2005).

\section{Methodology}

\subsection{Ethical aspects}

This study was approved by the Human Research Ethics Committee of the Federal University of São Carlos (CAAE: 33456720.9.0000.5504), following the Regulatory Guidelines and Norms for Research Involving Humans (Resolution $\mathrm{n}^{\circ}$ 510/2016, of the National Health Council and the Declaration of Helsinki). The mother of the infant signed the informed consent form and authorized the use of images. This case report followed the CARE guidelines (for CAse REports). CARE were developed by an international group of experts to support an increase in the accuracy, transparency, and usefulness of case reports (Gagnier et al. 2013).

\subsection{Case description}

Information regarding the infant was collected remotely, according to the mother's report and medical records sent via cell phone. The firstborn infant (born during the COVID-19 pandemic) of parents aging 35 and 39 years, male, 47,XY karyotype, +21 , was classified as a mild premature infant with 36 weeks gestational age (World Health Organization, 2018). Anthropometric data at birth were: weight (2,115 grams), length $(43.5 \mathrm{~cm})$, head and thoracic circumferences $(32$ and $28 \mathrm{~cm}$, respectively), and Apgar 9 (first minute) and 10 (fifth minute). Regarding the prenatal data, the mother did not report any difficulty in becoming pregnant. It was a planned pregnancy and with no history of previous abortions. She attended five prenatal consultations, and Down syndrome was not identified. The mother reported anxiety, neediness, and stress during pregnancy and practiced physical activities (yoga, Pilates, and walking). An emergency cesarean section was performed after identifying amniotic fluid loss and fetal hypomobility at 36 weeks gestational age. The infant was diagnosed with Down syndrome at birth and presented defects in body structures and functions, such as hypothyroidism, total atrioventricular septal defect $(3.5 \mathrm{~mm})$, and mild aortic and pulmonary valve regurgitation. No complications were observed in the peri- and postnatal periods.

Down syndrome was classified using the International Classification of Diseases and Related Health Problems (ICD10 Q90) (World Health Organization, 1997), while the functionality profile was characterized according to the ICF components.

\subsection{Procedures and assessments}

In May 2020, two months after the social isolation decree in the state of São Paulo (Brazil), the mother of a 35-dayold infant sought the physiotherapist responsible for the Early Intervention Program because the infant was diagnosed with Down syndrome at birth. 
The monitoring started with remote and synchronous interviews and identification of personal and environmental factors, body functions and structures, and activities and participation using the ICF. Qualifiers were used for the body function component to identify the magnitude of the defect, while magnitude, nature, and disability location qualifiers were used for body structure. The performance qualifier was used for the activity and participation component (i.e., those usually performed by the individual and influenced by environmental factors). In the environmental factors component, one barrier (not available or with no access) and one facilitator (available for the individual) were used (World Health Organization, 2001).

The socioeconomic level was classified using the poverty income ratio (PIR) associated with maternal education level (Karlamangla et al., 2010).

The Alberta Infant Motor Scale (AIMS) was used to assess the activity component, while the Brazilian version of the Affordances in the Home Environment for Motor Development - Infant Scale (AHEMD-IS) was used to identify the environmental factors.

The AIMS is validated, high reliable, and one of the most used instruments to assess the motor development of Down syndrome infants (Moryama et al. 2020). It is an observational scale that evaluates motor development sequence and is composed of 58 items subdivided into subscales (prone [21 items], supine [9 items], sitting [12 items], and standing [16 items] positions), considering weight unloading, posture, and antigravity movements. Thus, the AIMS allows qualitative and quantitative motor development assessment. The percentile corresponding to the total AIMS score of the infant was plotted on a graph, considering the chronological age of the full-term infant and the corrected age of the preterm infant. After this stage, the exact percentile of the infant was calculated; that is, when the intersection between the infant's age and total AIMS score was between two percentiles, the exact percentile was calculated (Tudella, Toledo, Lima-Alvarez, 2019).

According to previous studies (Piper, Darrah,1994; Darrah et al., 2014), the most appropriate percentiles to discriminate infants at the age of four months with atypical development would be the 10th. Thus, delayed motor development was determined in this study if less or equal to the percentile 10th, and the lower the AIMS percentile, the greater the probability of atypical motor development.

The AHEMD-IS was used to verify the quantity and quality of the stimulus offered in the home environment (affordances). This questionnaire assesses the home environment according to the physical space, variety of stimuli, and gross and fine motor skill toys, and classifies the home environment in less adequate (LA), moderately adequate (MA), adequate (A), and excellent (E). Thus, the score is generated qualitatively and quantitatively using the domains and the total score (Caçola et al., 2015; Caçola et al. 2015).

\subsection{Description of the intervention}

The early intervention objectives were defined according to the family expectations and clinical reasoning guided by the ICF biopsychosocial model focused on participation, activities, and body structures and functions (Figure 1). It is noteworthy that all the ICF components interact with each other because it is a multidimensional model.

Early intervention strategies were based on the typical development process of the infant, including strategies to facilitate looking at the mother's face and objects, head control, strengthen the neck and trunk muscles; stimulate oculocephalic, audio-cephalic, audio-visual-cephalic, mouth-eye, and hand-mouth coordination; stimulate the infant in different postures (e.g., prone, sitting, and standing), suction, spontaneous upper and lower limb movements, the passage of the upper limbs; grasp under tactile control; palm orientation; and manipulative skills with different textures and objects (Tudella, Toledo, Lima-alvarez, 2019). 
Figure 1. Interaction between the ICF components and early intervention strategies.

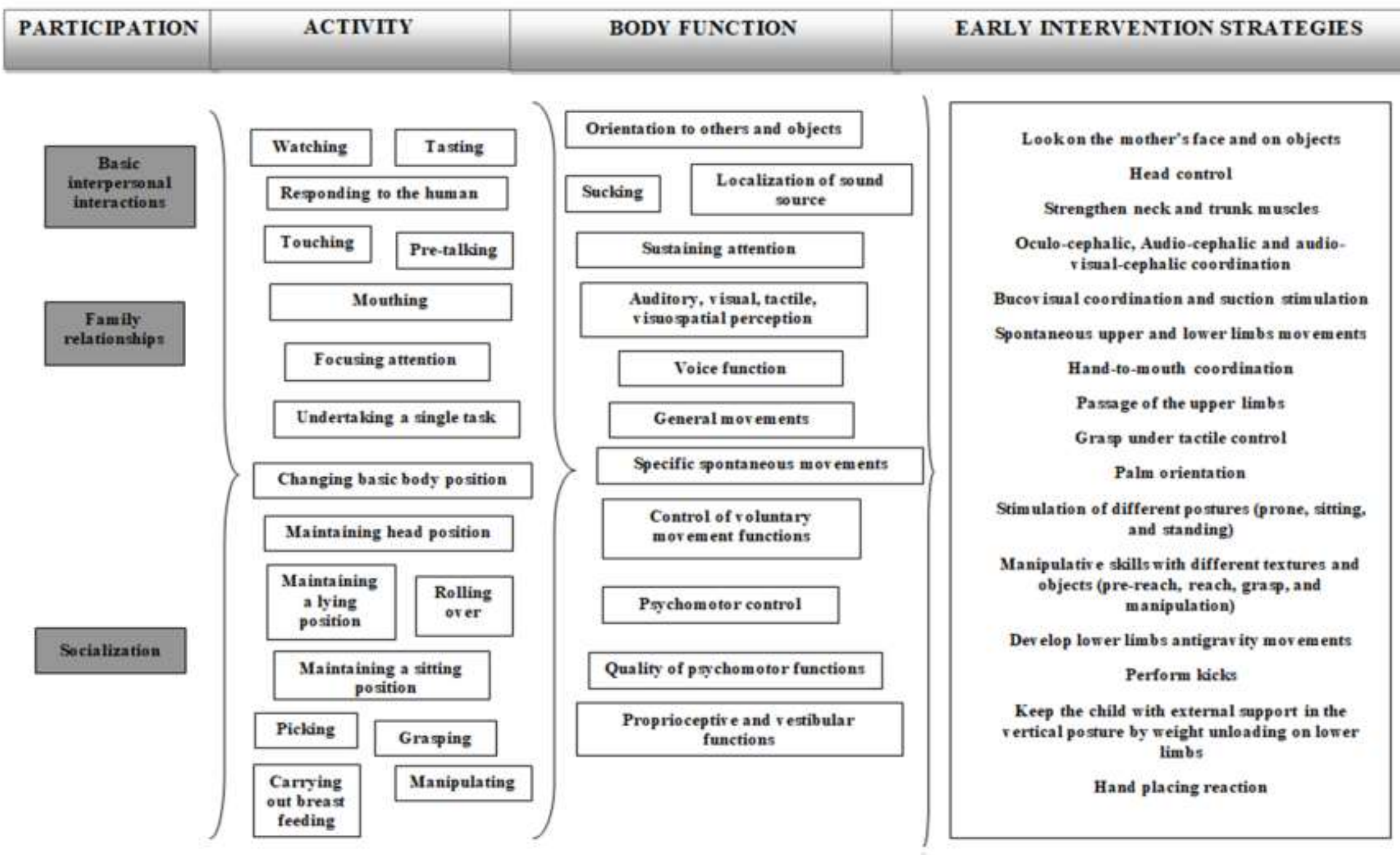

Source: Own authorship. 
The total time of early intervention using telehealth was 98 days. Telehealth was performed asynchronously in the first 30 days and hybrid (i.e., synchronous and asynchronous moments) in the remaining days. The latter was performed using hybrid telehealth and according to the mother's preference, who felt calmer when received videos containing activities before the real-time visits, in which the physiotherapist performed the activities synchronously with the mother.

The physiotherapist sent videos via cell phone performing the activities on an articulated doll and scheduled a video call (also via cell phone) to answer the mother's doubts and perform the same activities on the doll while the mother performed on the infant. This kind of intervention used to calm down the mother and prevented the infant from missing the treatment when the internet was unstable.

Before each session, whether synchronously or asynchronously, the physiotherapist guided the mother to adequate the home environment for the physiotherapy session. The environment should have a pleasant, calm, and quiet temperature for the infant to receive the stimuli and perform the self-generated activities. The environment should also be suitable for the mother to perform the activities without causing postural impairments.

The materials and equipment used were those already present at home or adapted to our objectives. After guidance, the physiotherapist demonstrated the stimuli on a doll and informed the expected responses. The mother was asked to be patient and wait for the infant's response since the threshold between stimulus and feedback could be relatively long due to the infant's health condition.

The mother should also observe the facial and body expressions of the infant. The activity was stopped when the infant disliked the received stimuli, frowning, arching his back, grumbling, or crying. We explained that the activities should be pleasant to motivate the infant to actively repeat the trained activities.

During early intervention using telehealth, the physiotherapist must provide tranquility and confidence to the mother and guide the activities within the family context.

The family was instructed to continue performing the activities throughout the day during moments of social interaction and daily care, according to disposition and motivation of the infant. A mean frequency of three times daily and at different daytimes was suggested to the family; however, the frequency and duration should be determined by the infant (i.e., until when demonstrating dislike expressions, such as arching the trunk and/or presenting facial expressions of crying). Once the objectives were achieved, new and more complex activities were proposed.

\section{Results}

The infant's family had a high socioeconomic status, according to the PIR. The evaluation process comprised an interview to identify the family's demand, observe the infant, and apply the instruments. This was divided into four moments: $5,50,79$, and 105 days corrected age (Tables 1 and 2).

Table 1. Motor development assessment according to the Alberta Infant Motor Scale (AIMS).

\begin{tabular}{lcccc}
\hline \multicolumn{1}{c}{ Posture } & $\begin{array}{c}1^{\text {st }} \text { assessment } \\
(5 \text { days corrected } \\
\text { age })\end{array}$ & $\begin{array}{c}2^{\text {nd }} \text { assessment } \\
(50 \text { days corrected } \\
\text { age })\end{array}$ & $\begin{array}{c}3^{\text {rd }} \text { assessment } \\
(79 \text { days corrected } \\
\text { age })\end{array}$ & $\begin{array}{c}4^{\text {th }} \text { assessment } \\
(105 \text { days corrected } \\
\text { age })\end{array}$ \\
\hline Prone & 1 & 1 & 3 & 3 \\
Supine & 0 & 3 & 4 & 6 \\
Seated & 0 & 0 & 1 & 1 \\
Standing & 1 & 1 & 2 & 2 \\
Total score & 2 & 5 & 10 & 12 \\
Exact percentile & $10 \%$ & $20 \%$ & $50 \%$ & $58 \%$ \\
\hline
\end{tabular}

Source: Own authorship. 
The ICF qualifiers were assigned longitudinally considering the physiotherapists' perception, the mother, the instruments, and the qualitative assessment of the ICF qualifiers according to corrected age (table 2).

Table 2. Longitudinal follow-up of the infant using the ICF qualifiers.

\begin{tabular}{|c|c|c|c|c|c|}
\hline Components & Categories & $\begin{array}{c}1^{\mathbf{a}} \\
\text { asses. }\end{array}$ & $\begin{array}{c}2^{\mathbf{a}} \\
\text { asses. }\end{array}$ & $\begin{array}{c}3^{\mathbf{a}} \\
\text { asses. }\end{array}$ & $\begin{array}{c}4^{a} \\
\text { asses. }\end{array}$ \\
\hline \multirow{24}{*}{ Body structures and function } & b11421- Orientation to others & .3 & .2 & .0 & .0 \\
\hline & b1143- Orientation to objects & .3 & .2 & .1 & .1 \\
\hline & b1400- Sustaining attention & .3 & .2 & .1 & .1 \\
\hline & b1470 - Psychomotor control & .3 & .2 & .1 & .1 \\
\hline & b1471- Quality of psychomotor functions & .3 & .2 & .1 & .1 \\
\hline & b1560 - Auditory perception & .3 & .1 & .0 & .0 \\
\hline & b1561 - Visual perception & .3 & .1 & .0 & .0 \\
\hline & b1564 - Tactile perception & .2 & .1 & .1 & .1 \\
\hline & b1565 - Visuospatial perception & .3 & .1 & .0 & .0 \\
\hline & b2300 - Sound detection & .3 & .1 & .0 & .0 \\
\hline & b2302- Localization of sound source & .3 & .1 & .0 & .0 \\
\hline & b235 - Vestibular functions & .2 & .2 & .2 & .2 \\
\hline & b260 - Proprioceptive functions & .2 & .2 & .2 & .2 \\
\hline & b310 - Voice function & .3 & .1 & .0 & .0 \\
\hline & b340 - Alternative vocalization functions & .3 & .1 & .0 & .0 \\
\hline & b5100 - Sucking & .2 & .0 & .0 & .0 \\
\hline & b7102- Mobility of joints generalized & .3 & .2 & .2 & .2 \\
\hline & b7306 - Power of all muscles of the body & .3 & .3 & .2 & .2 \\
\hline & b7356 - Tone of all muscles of the body & .2 & .2 & .2 & .2 \\
\hline & $\begin{array}{l}\text { b760 - Control of voluntary movement } \\
\text { functions }\end{array}$ & .4 & .2 & .1 & .0 \\
\hline & b7610- General movements & .3 & .2 & .1 & .1 \\
\hline & b7611- Specific spontaneous movements & .3 & .1 & .1 & .1 \\
\hline & s7701 - Joints & .270 & .170 & .170 & .170 \\
\hline & s7702-Muscles & .270 & .170 & .170 & .170 \\
\hline \multirow{19}{*}{ Activities and participation } & d110 - Watching & .3 & .1 & .0 & .0 \\
\hline & d1200 - Mouthing & .4 & .2 & .1 & .0 \\
\hline & d1201 - Touching & .4 & .2 & .1 & .0 \\
\hline & d1203 - Tasting & .2 & .1 & .0 & .0 \\
\hline & $\begin{array}{l}\text { d1601 - Focusing attention to changes in the } \\
\text { environment }\end{array}$ & .3 & .2 & .1 & .1 \\
\hline & $\mathrm{d} 210-$ Undertaking a single task & .3 & .2 & .2 & .1 \\
\hline & d3100 - Responding to the human voice & .4 & .2 & .0 & .0 \\
\hline & d331 - Pre-talking & .4 & .2 & .0 & .0 \\
\hline & d410- Changing basic body position & .4 & .3 & .2 & .1 \\
\hline & $\mathrm{d} 4107-$ Rolling over & .4 & .3 & .2 & .2 \\
\hline & d4150 - Maintaining a lying position & .3 & .1 & .0 & .0 \\
\hline & d4153 - Maintaining a sitting position & .4 & .4 & .3 & .2 \\
\hline & d4155 - Maintaining head position & .4 & .3 & .2 & .1 \\
\hline & d4400 - Picking up & .4 & .3 & .2 & .1 \\
\hline & d4401 - Grasping & .4 & .3 & .2 & .1 \\
\hline & d4402 - Manipulating & .4 & .3 & .3 & .2 \\
\hline & d4452 - Reaching & .4 & .2 & .1 & .1 \\
\hline & d5601 - Carrying out breast feeding & .1 & .0 & .0 & .0 \\
\hline & $\mathrm{d} 710$ - Basic interpersonal interactions & .4 & .1 & .0 & .0 \\
\hline
\end{tabular}


Research, Society and Development, v. 10, n. 5, e20210514900, 2021

(CC BY 4.0) | ISSN 2525-3409 | DOI: http://dx.doi.org/10.33448/rsd-v10i5.14900

\begin{tabular}{|c|c|c|c|c|c|}
\hline & d760 - Family relationships & .4 & .1 & .0 & .0 \\
\hline & d9205 - Socializing & .4 & .3 & .3 & .3 \\
\hline \multirow{9}{*}{ Environmental factors } & e1101 - Drugs & +8 & +8 & +8 & +8 \\
\hline & e1100 - Food & +8 & +8 & +8 & +8 \\
\hline & $\begin{array}{c}\text { e1400 - General products and technology for } \\
\text { culture, recreation and sport }\end{array}$ & .8 & +8 & +8 & +8 \\
\hline & e230 - Natural events & .8 & .8 & .8 & .8 \\
\hline & e310 - Immediate family & .8 & +8 & +8 & +8 \\
\hline & $\begin{array}{l}\text { e410 - Individual attitudes of immediate family } \\
\text { members }\end{array}$ & .8 & +8 & +8 & +8 \\
\hline & e350 - Domesticated animals & +8 & +8 & +8 & +8 \\
\hline & e355 - Health professionals & .8 & .8 & .8 & .8 \\
\hline & $\begin{array}{l}\text { e398 - Support and relationships, other } \\
\text { specified }\end{array}$ & .8 & .8 & .8 & .8 \\
\hline
\end{tabular}

Asses: Assessment. Source: Own authorship.

Regarding the first and last AHEMD-IS assessments (50 and 105 days corrected age, respectively), the following scores were found in the domains: physical space 2 (MA) and 2 (MA), variety of stimulation 10 (MA) and 11 (MA), gross motor skill toys 6 (A) and 6 (A), and fine motor skill toys 2 (LA) and 3 (MA). The total score in the first assessment was 20 (MA) and in the last was 22 (MA). The moderately adequate environment indicated moderate opportunities (affordances) for motor development, and these were improved slightly over time.

\section{Discussion}

This study aimed to present the strategies used and the results of early physiotherapy intervention performed on a Down syndrome infant using telehealth. It is the first study in Brazil to report the report the early physiotherapy intervention using telehealth following the biopsychosocial model. Therefore, the results of this study provide scientific evidence to support early intervention using telehealth.

The infant in this study presented a total percentile of 10 in the AIMS at five days corrected age. In the case of a firstborn infant diagnosed with Down syndrome, born in an unfavorable time to motor development due to the COVID-19 pandemic, with several changes in body structures and functions, and further motor delay (Pereira et al., 2013; Tudella et al., 2011), we considered initiating the early intervention immediately.

It was found that early intervention using telehealth led to motor development benefits since the AIMS score in the supine and sitting postures was zero in the first assessment (5 days corrected age), and the total score was 2 (percentile 10th), indicating delayed motor development. After 74 days of early intervention (at 79 days corrected age), the infant showed gains in all postures and reached a total AIMS score of 10 (percentile 50th). At this point, the infant achieved a motor development compatible with $50 \%$ of children from the same age group assessed by AIMS. This result confirms the importance of early intervention using telehealth to obtain gains in quantity and quality of motor skills.

It is essential to highlight that between the first and fourth evaluation, when the infant was 105 days corrected age, he obtained a total AIMS score of 12 (percentile 58th). Thus, the infant who initially presented the percentile 10th reached the percentile 58th after 100 days of early intervention using telehealth. It must be highlighted that the infant obtained progressive and constant gains during the early intervention period, improving the skills in supine, performing antigravity movements, and acquiring skills in prone and sitting. These results agree with those found by Hauck et al. (Hauck, Felzer-Kim, Gwizdala, 2020) however, difficulties in maintaining the head at $45^{\circ}$ while prone were still present. This result is similar to previous studies that observed changes in the motor development process of Down syndrome infants (Tudella et al. 2011; Winders, 
Wolter-Warmerdam, Hickey,2019) and difficulties in acquiring antigravity control and movements, mainly in prone, sitting, and standing postures (Tudella et al. 2011).

Early intervention strategies were planned to achieve specific activities focused on social participation, according to family expectations. When intervening with the activity and participation and body structures and functions components, it is necessary to think about the infant according to the biopsychosocial model. Besides, environmental factors (materials, home space, attitudes, and family support) and personal factors (motivation) also interfere with skill performance.

Corroborating with Hadders-Algra et al. 2017 (Hadders-Algra et al., 2017) the results of this study allowed us to state that the sooner the early intervention begins, the better the neuropsychomotor development. Improvements were observed in the performance of activities mainly due to the task-oriented training, the self-generated movements proposed in the early intervention (Tudella et al.,2000; de Lima-Alvarez et al., 2013; Cunha et al., 2016; Soares et al., 2013; Guimarães et al.,2013; Landgraf, Tudella, 2008; Dionisio, Santos, Tudella,2017), and the active participation of the parents. Corroborating with Dustin et al. (Dusing et al., 2020), our results indicate that the active participation of parents in early intervention is essential for the infant evolution. This improvement led to beneficial changes in body functions, mother-infant interaction, and social participation, which were the primary family demands. These results can be observed in table 2 .

It is important to highlight that Down syndrome individuals will need physiotherapy intervention at all stages of life to remain functional and active (Hardee, Fetters, 2017).

Initially, six environmental factors were identified as barriers to motor development: products and technology (toys in the environment), the COVID-19 pandemic, nuclear family, individual attitudes of the nuclear family members, health professionals, and support and relationships. Social isolation was the main environmental barrier since the access to health professionals recommended for Down syndrome (e.g., occupational therapists and speech therapists) was challenging for the family. Also, the contact between infants and other nuclear family members (e.g., grandparents) who could assist the parents in supporting, caring for the infants, and encouraging their socialization was impossible.

The infant presented as environmental facilitators at the beginning of the follow-up period only food (exclusive breastfeeding), medicines, and domestic animals. After analyzing and guiding the mother regarding the importance of environmental factors, three environmental factors became motor development facilitators: the family attitude, the nuclear family, and the access to products and technology (toys for fine and gross motricity). These findings corroborate with Anjos et al. (Anjos et al., 2019) that highlighted the nuclear family support as the main facilitator for the performance of Down syndrome infants, while the access to multidisciplinary health professionals was a barrier.

The AHEMD-IS was essential to know the maternal attitudes and analyze the home environment. This instrument allowed the physiotherapist to observe that the mother was not using toys present in the home environment to stimulate the infant because he was very young. The physiotherapist instructed the mother to make toys with recyclable materials (Cunha, Miquelote, Santos, 2018) and use the toys already present at home to encourage gross and fine motor skills. She was instructed to place the infant in prone for "tummy time", leave the infant free to move on the floor, expose to various sensory textures, and allow the dog to coexist as potential sensory stimuli. This information promptly increased the scores in a variety of stimulation and fine motor skills domains. In general, changes in the total AHEMD-IS score were observed, and could not be higher due to social isolation and the residence (apartment). Thus, we were unable to allow new physical environment possibilities (e.g., squares and playgrounds). This change was also observed in the ICF environmental factor qualifiers (table 2).

The success of early intervention using telehealth is one more piece of information to be considered. Corroborating with Dantas et al. (Dantas, Barreto, Ferreira,2020) we believe that this was due to the high socioeconomic level of the family, the high education level, and the access to communication technology, such as the internet and cell phones. In this sense, the 
mother's response to the intervention using telehealth was: "I feel very well assisted during telemonitoring, and I can understand the activities and develop them at home. It has been a great tool in this pandemic period. There is a little bit of insecurity about the way I am doing it. But hearing from the professional that my son is evolving reassures me". In addition, it is noted that parents and physiotherapists are satisfied when carrying out the early intervention through telehealth (Formiga et al., 2021).

This report corroborates the hypothesis that telehealth can be an excellent strategy to support families needing early intervention. However, it also offers disadvantages, such as the lack of face-to-face practice with the physiotherapist and the access to the internet, cellphones, computers, and ease of handling such instruments by those families with low socioeconomic status and educational level (Dantas, Barreto, Ferreira,2020; Digital Practice White Paper and Survey, 2020).

The home program suggested by Novak and Cusick (Novak, Cusick, 2006) was successfully used in the present study. The interview was conducted remotely, synchronously, and guided by the ICF checklist to identify the personal and environmental factors, body functions and structures, and activities and participation. For this purpose, validated and standardized assessment instruments were used. The ICF checklist and the AHEMD-IS were used to identify the home environment; the objectives proposed in the early intervention were planned in partnership with the family and according to the home environment; support and regular guidance was provided to the family during weekly online meetings and via cell phone; the early intervention strategies employed favored self-generated movements and task-oriented training; and systematic and continuous motor development reassessments were conducted to adapt the intervention according to the infant's evolution.

\section{Implications for Rehabilitation}

- The sooner the early intervention begins, the sooner the infants will experience the potential for neuropsychomotor development. Thus, we suggest that early intervention for risk infants should start before the age of 4 months and based on the biopsychosocial model together with intervention strategies using selfgenerated movements and task-oriented training.

- Telehealth was an important early intervention tool during the social isolation period due to the COVID-19 pandemic and, therefore, must be maintained to complement and optimize access to specialized services and guide early intervention programs.

- The physiotherapist must understand the tool, practice, and be prepared since confidence, serenity, and support is essential for the family in Telehealth.

\section{Study limitations}

Telehealth is a new possibility to offer early intervention in Brazil. However, studies with bigger sample size and robust methodological designs (i.e., longitudinal studies and clinical trials) are needed in the area.

\section{Conclusion}

In short, the early intervention strategies carried out using telehealth were specific self-generated activities, directed to the objective, and reverberated on body structures and functions. Early intervention initiated in the first month of life using telehealth in an infant with Down syndrome proved an effective intervention method.

\section{Acknowledgments}

We thank the family members for participating in the research and the São Paulo State Research Support Foundation (FAPESP), process n 2018/24930-0. 


\section{Author contribution}

ET contributed to the conception, design of this study, the data collection and to write of the manuscript; CFRS to the design of this study, the data collection and to write of the manuscript; CCAV critically reviewed the manuscript and contributed the whole analysis datas and to write of the manuscript. All authors read and approved the final manuscript.

\section{Declaration of interest statement}

The authors report no conflicts of interest.

\section{References}

Anjos, C. C. D, Miranda, J. S, Brandão, J. F, Soutinho, R. S. R, Santos, S. S, \& Wanderley, T. C. F (2019). Fatores ambientais das crianças com Síndrome de Down conforme a Classificação Internacional de Funcionalidade, Incapacidade e Saúde (CIF). Cadernos de Pós-Graduação em Distúrbios do Desenvolvimento, 19:9-24.

Araujo, L. A., Veloso, C. F., Souza, M. C., Azevedo, J. M. C., \& Tarro, G. (2020). The potential impact of the COVID-19 pandemic on child growth and development: a systematic review. J Pediatr (Rio J).

Brandão J.S (1992). Bases dos tratamentos por estimulação precoce em paralisia cerebral (ou dismotria cerebral ontogenética). São Paulo: Mennon.

Brazilian Federation of Down Syndrome Associations. Síndrome de Down. O que é a síndrome de Down. 2020 October 6], Available from: http://federacaodown.org.br/sindrome-de-down/.

Caçola, P. M, Gabbard, C, Montebelo, M. I, \& Santos, D. C (2015). Further Development and Validation of the Affordances in the Home Environment for Motor Development-Infant Scale (AHEMD-IS). Phys Ther.95:901-23.

Caçola, P.M, Gabbard,, C, Montebelo, M. I, \& Santos, D. C (2015).The new affordances in the home environment for motor development - infant scale (AHEMD-IS): Versions in English and Portuguese languages. Braz J Phys Ther 19:507-25.

COFFITO. Resolução n. 516. https://www.coffito.gov.br/nsite/?p=15825.

Contestabile A, Benfenati F, Gasparini L (2010). Communication breaks-Down: from neurodevelopment defects to cognitive disabilities in Down syndrome. Prog Neurobiol. 91:1-22.

Cunha, A. B, Lobo, M. A, Kokkoni, E, Galloway, J. C, \& Tudella E (2016). Effect of Short-Term Training on Reaching Behavior in Infants: A Randomized Controlled Clinical Trial. J Mot Behav. 48:132-42.

Cunha, A. B, Miquelote, A. F, \& Santos, D. C. C (2018). Motor affordance at home for infants living in poverty: A feasibility study. Infant Behavior and Development. 51:52-9.

Dantas, L. O, Barreto, R. P. G, \& Ferreira, C. H. J (2020). Digital physical therapy in the COVID-19 pandemic. Braz J Phys Ther,24:381-3.

Darrah, J, Bartlett, D, Maguire, T. O, Avison, W. R., \& Lacaze-Masmonteil T (2014). Have infant gross motor abilities changed in 20 years? A re-evaluation of the Alberta Infant Motor Scale normative values. Dev Med Child Neurol.56:877-81.

de Lima-Alvarez, C. D., Tudella, E., van der Kamp, J., 7 Savelsbergh G. J (2013). Effects of postural manipulations on head movements from birth to 4 months of age. J Mot Behav. 45:195-203.

Digital Practice White Paper and Survey (2020). Available from: http://www.inptra.org/Resources/DigitalPracticeWhitePaperandSurvey.aspx.

Dionisio, J., Santos, G. L. D, \& Tudella E. (2017). Influence of Additional Ankle Weights on Kinematic Variables of Late Preterm Infants Aged 3-4 Months. J Mot Behav 49:306-11.

Dusing, S. C, Burnsed, J. C, Brown, S. E, Harper, A. D, Hendricks-Munoz, K. D, Stevenson, R. D, Thacker, L. R, \& Molinini, R. M (2020). Efficacy of Supporting Play Exploration and Early Development Intervention in the First Months of Life for Infants Born Very Preterm: 3-Arm Randomized Clinical Trial Protocol. Phys Ther. 100:1343-52.

Farias, N, Buchalla, C.M (2005). A classificação internacional de funcionalidade, incapacidade e saúde da organização mundial da saúde: conceitos, usos e perspectivas. Revista Brasileira de Epidemiologia.8:187-93.

Ferreira-Vasques, A. T., \& Lamonica, D. A. Motor, linguistic, personal and social aspects of children with Down syndrome (2015). J Appl Oral Sci,23:424-30.

Formiga, C. K. M. R., Dionisio, J., Silva, C. F. R., \& Tudella, E (2021). Caregivers and Physical therapists' Perceptions of Telehealth for infants with Down Syndrome during COVID-19: Case reports. Research, Society and Development, v. 10, n. 3, p. e27710313460, 2021. DOI: 10.33448/rsd-v10i3.13460.

Gagnier, J. J., Kienle, G., Altman, D. G., et al. The CARE guidelines: consensus-based clinical case reporting guideline development.BMJ Case Rep. 2013:2013.

Greco, A. L. R., Silva, C. F. R. da, Moraes, M. M. de, Menegussi , J. M., \& Tudella, E. (2021). Impact of the COVID-19 pandemic on quality of life, health and income in families with and without socioeconomic risk: a cross-sectional study. Research, Society and Development, 10(4), e29410414094. 
https://doi.org/10.33448/rsd-v10i4.14094

Guimarães, E. L, Cunha, A. B, Soares, D. A, \& Tudella, E (2013). Reaching behavior in preterm infants during the first year of life: a systematic review. Motor Control. 17:340-54.

Hadders-Algra M (2011). Challenges and limitations in early intervention. Dev Med Child Neurol,53 Suppl 4:52-5.

Hadders-Algra, M, Boxum, A. G, Hielkema, T, \& Hamer, E. G. Effect of early intervention in infants at very high risk of cerebral palsy: a systematic review (2017). Dev Med Child Neurol,59:246-58.

Hardee, J. P, \& Fetters L (2017). The effect of exercise intervention on daily life activities and social participation in individuals with Down syndrome: A systematic review. Res Dev Disabil,62:81-103.

Hauck, J. L., Felzer-Kim, I. T., \& Gwizdala, K. L. (2020). Early Movement Matters: Interplay of Physical Activity and Motor Skill Development in Infants With Down Syndrome. Adapt Phys Activ Q. 37:160-76.

Herskind A, Greisen G, \& Nielsen J. B (2015). Early identification and intervention in cerebral palsy. Dev Med Child Neurol. 57:29-36.

Ismail F.Y, Fatemi A, \& Johnston M. V (2017). Cerebral plasticity: Windows of opportunity in the developing brain. Eur J Paediatr Neurol.21:23-48.

Karlamangla A. S, Merkin S. S, Crimmins E. M, \& Seeman T. E (2010). Socioeconomic and ethnic disparities in cardiovascular risk in the United States, 2001-2006. Ann Epidemiol. 20:617-28.

Landgraf, J, \& Tudella E (2008). Efeitos do peso externo nos chutes espontâneos de lactentes nos primeiros dois meses de vida. Brazilian Journal of Physical Therapy. 12:468-75.

Lauteslager P.E.M, Volman M, Lauteslager T, Van den Heuvel M. E, Jongerling J, \& Klugkist I. G. (2020) Basic Motor Skills of Children With Down Syndrome: Creating a Motor Growth Curve. Pediatr Phys Ther,32:375-80.

Minghelli, B, et al. (2020). Physiotherapy services in the face of a pandemic. Rev Assoc Med Bras. 66:491-7.

Ministério da Saúde (2013). Secretaria de Atenção à Saúde. Departamento de Ações Programáticas Estratégicas. Diretrizes de atenção à pessoa com Síndrome de Down. Available from: https://bvsms.saude.gov.br/bvs/publicacoes/diretrizes_atencao_pessoa_sindrome_down.pdf.

Ministério da Saúde do Brasil (2019). "Não deixe ninguém para trás": Dia Internacional da Síndrome de Down. http://bvsms.saude.gov.br/ultimasnoticias/2916-nao-deixe-ninguem-para-tras-dia-internacional-da-sindrome-de-

down2020\#: :text=Estima\%2Dse\%20que\%20no\%20Brasil,em\%201\%20mil\%20nascidos\%20vivs.

Moriyama C. H. et al (2020). Systematic Review of the Main Motor Scales for Clinical Assessment of Individuals with down Syndrome. Dev Neurorehabil 2020,23:39-49.

Novak, I., \& Cusick, A. (2006). Home programmes in paediatric occupational therapy for children with cerebral palsy: Where to start? Australian Occupational Therapy Journal. 53:251-64.

Novak, I. et al. (2017). Early, Accurate Diagnosis and Early Intervention in Cerebral Palsy: Advances in Diagnosis and Treatment. JAMA Pediatr. 171:897907.

Organização Mundial da Saúde. CID-10 Classificação Estatística Internacional de Doenças e Problemas Relacionados à Saúde. 1997.

Pereira, K., Basso, R. P., Lindquist, A. R., da Silva, L. G., \& Tudella, E. (2013). Infants with Down syndrome: percentage and age for acquisition of gross motor skills. Res Dev Disabil.34:894-901.

Pinero-Pinto, E., Benitez-Lugo, M. L., Chillon-Martinez, R., Rebollo-Salas, M., Bellido-Fernandez, L. M., \& Jimenez-Rejano, J. J. (2020). Effects of Massage Therapy on the Development of Babies Born with Down Syndrome. Evid Based Complement Alternat Med 2020.4912625.

Piper, M., \& Darrah, J. (1994). Motor assessment of the developing infant. WB Saunders Company.

Schwartzman, J. S. (2003). Síndrome de Down: Generalidades. Memnon.

Soares, D, van der Kamp, J, Savelsbergh, G. J, \& Tudella, E (2013). The effect of a short bout of practice on reaching behavior in late preterm infants at the onset of reaching: a randomized controlled trial. Res Dev Disabil. 34:4546-58.

Tomopoulos, S, Dreyer B. P, Tamis-LeMonda, C, Flynn, V, Rovira, I, Tineo, W, \& Mendelsohn, A. L (2006). Books, toys, parent-child interaction, and development in young Latino children. Ambul Pediatr. 6:72-8.

Tudella, E., Oishi, J., \& Puglia Bergamasco, N..H. (2000). The effect of oral-gustatory, tactile-bucal, and tactile-manual stimulation on the behavior of the hands in newborns. Dev Psychobiol. 37:82-9.

Tudell,a E, Pereira, K, Basso, R. P., \& Savelsbergh, G. J (2011). Description of the motor development of 3-12 month old infants with Down syndrome: the influence of the postural body position. Res Dev Disabil. 32:1514-20.

Tudella, E., Toledo, A. M., \& Lima-Alvarez, C. D. (2019). Intervenção precoce: Evidências para a prática clínica em lactentes de risco. Appris.

Tudella E. (1989). Tratamento precoce no desenvolvimento neuromotor de crianças com diagnóstico sugestivo de paralisia cerebral. Universidade Gama Filho.

Winders P,, Wolter-Warmerdam, K., \& Hickey, F. (2019). A schedule of gross motor development for children with Down syndrome. J Intellect Disabil Res. 63:346-56. 
Research, Society and Development, v. 10, n. 5, e20210514900, 2021

(CC BY 4.0) | ISSN 2525-3409 | DOI: http://dx.doi.org/10.33448/rsd-v10i5.14900

World Health Organization (2020). Coronavirus disease (COVID-19) advice for the public. https://www.who.int/emergencies/diseases/novel-coronavirus2019.

World Health Organization (2020). Human Genomics in Global Health. SGenes and human diseases. https://www.who.int/genomics/public/ge neticdiseases/en/.

World Health Organization. International classification of functioning, disability and health: ICF.

World Health Organization. Preterm birth. (2018), Available from: https://www.who.int/news-room/fact-sheets/detail/preterm-birth. 